\title{
KARAKTERISTIK PERMUKIMAN KAMPUNG TEMATIK DI KOTA MALANG
}

\author{
Adhi Widyarthara \\ Dosen Prodi Arsitektur, Fak. Teknik Sipil dan Perencanaan, ITN Malang \\ e-mail: adhiwidyarthara@gmail.com \\ Amar Rizqi Afdholy \\ Dosen Prodi Arsitektur, Fak. Teknik Sipil dan Perencanaan, ITN Malang \\ e-mail: amarrizqi@lecturer.itn.ac.id
}

\begin{abstract}
ABSTRAK
Kota Malang merupakan salah satu kota di Jawa Timur yang memiliki kepadatan penduduk yang cukup tinggi dengan pertumbuhan dan perkembangan kotanya yang cukup pesat. Keterbatasan lahan tempat tinggal memberikan dampak pada terbentuknya permukiman yang tidak terkontrol, hal ini menimbulkan permasalahan pada munculnya permukiman-permukiman kumuh yang ada di Kota Malang. Salah satu program Pemerintah Kota Malang dalam menekan angka kekumuhan ini dengan pembuatan Kampung Tematik. Selain untuk memecahkan masalah terkait permukiman, kampung tematik ini juga diupayakan dapat menjadi objek wisata Kota Malang dan membantu dalam sektor perekonomian masyarakatnya. Fenomena perkembangan keberagaman kampung tematik tersebut sangat menarik untuk dikaji dari sisi bagaimana karakteristik permukimannya. Tujuan dari penelitian ini adalah untuk menganalisis karakteristik dari permukiman kampung tematik di Kota Malang. Metode yang digunakan dalam penelitian ini, yaitu menggunakan metode penelitian deskriptif kualitatif dengan melihat kondisi permukiman langsung ke lapangan. Hasil yang didapatkan dari karakteristik permukiman pada kampung tematik tersebut memiliki keragaman dalam hal aspek alam dan lindungan, sedangkan keseragaman dapat terlihat dari aspek social masyarakat dan jaringan.
\end{abstract}

\section{Kata kunci : Permukiman, Kampung Tematik, Kota Malang}

\begin{abstract}
Malang City is one of the cities in East Java which has a fairly high population density with a fairly rapid growth and development of the city. The limitation of residential land has an impact on the formation of uncontrolled settlements, this causes problems in the emergence of slum settlements in Malang City. One of the Malang City Government programs in reducing the number of slums is the creation of Thematic Villages. In addition to solving problems related to settlements, this thematic village is also sought to become a tourist attraction for Malang City and help in the economic sector of the community. The phenomenon of the development of the diversity of thematic villages is very interesting to study in terms of
\end{abstract}

PAWON: Jurnal Arsitektur, Nomor 01 Volume VI, Januari - Juni Tahun 2022, ISSN 2597-7636 
how the characteristics of the settlements are. The purpose of this study was to analyze the characteristics of thematic village settlements in Malang City. The method used in this study, namely using a qualitative descriptive research method by looking at the conditions of settlements directly to the field. The results obtained from the characteristics of the settlements in the thematic villages have diversity in terms of natural and protected aspects, while uniformity can be seen from the social and network aspects of the community.

\section{Keywords : Settlements, Thematic Villages, Malang City}

\section{PENDAHULUAN}

Kota Malang merupakan salah satu kota di Jawa Timur yang memiliki kepadatan penduduk yang cukup tinggi dengan pertumbuhan dan perkembangan kotanya yang cukup pesat. Hal ini menimbulkan permasalahan pada munculnya permukiman-permukiman kumuh yang ada di Kota Malang. Menurut SK kumuh Kota Malang (2015), Kota malang memiliki total luasan Kawasan kumuh sebesar 608,6 Ha yang tersebar di setiap kelurahannya. Salah satu program Pemerintah Kota Malang dalam menekan angka kekumuhan ini dengan pembuatan Kampung Tematik. Selain untuk memecahkan masalah terkait permukiman, kampung tematik ini juga diupayakan dapat menjadi objek wisata Kota Malang dan membantu dalam sektor perekonomian masyarakatnya. Menurut Martuti et al (2017), pada program kampung tematik diharapkan keterlibatan partisipasi masyarakat beserta lembaga-lembaga, yang bertujuan untuk membangun trademark / karakteristik lingkungan melalui peningkatan / pengembangan potensi-potensi lokal yang dimiliki di wilayah tersebut.

Perkembangan kampung tematik dalam beberapa tahun terakhir di Kota Malang sudah mulai menjadi tren pada permukiman atau kampungkampung kota. Masyarakat sedikit demi sedikit sudah mulai sadar akan potensi dan keberlanjutan lingkungannya, sehingga dengan bantuan Pemerintah atau lembaga-lembaga dapat bekerjasama untuk pembangunan kawasan permukimannya. Sampai saat ini Kota Malang sudah memiliki lebih dari 15 kampung tematik yang tersebar di seluruh Kecamatannya, diantara lain seperti Kampung Tridi, Kampung Lampion, Kampung Keramik Dinoyo, Kampung Warna Warni, Kampung Biru Arema, Kampung Budaya Polowijen dan Kampoeng Kajoetangan Heritage.

Fenomena dari perkembangan keberagaman kampung tematik tersebut timbul permasalahan yang dapat dikaji, yaitu bagaimana karakteristik permukimannya dari beberapa kasus kampung tematik di Kota Malang. Sehingga diharapkan tujuan dari penelitian ini nantnya akan

PAWON: Jurnal Arsitektur, Nomor 01 Volume VI, Januari - Juni Tahun 2022, ISSN 2597-7636 
didapatkan karakteristik permukiman dari beberapa kampung tematik di Kota Malang.

\section{TINJAUAN PUSTAKA}

\subsection{Tinjauan Permukiman}

Secara umum permukiman dapat diartikan sebagai sebuah kawasan atau lingkungan yang ditempati sekelompok masyarakat dengan kebutuhan untuk berhuni dalam jangka waktu yang cukup lama. Menurut UndangUndang Nomor 1 (2011), Kawasan Permukiman adalah bagian dari lingkungan hidup di luar kawasan lindung, baik berupa kawasan perkotaan maupun perdesaan, yang berfungsi sebagai lingkungan tempat tinggal atau lingkungan hunian dan tempat kegiatan yang mendukung perikehidupan dan penghidupan. Jika dilihat dari unsur fisik, terdapat unsur-unsur utama pembentuk suatu permukiman, yaitu manusia, kelompok sosial, alam, fasilitas dan jaringan penghubung (Doxiadis, 1968). Sedangkan dari unsur non fisik, permukiman terbentuk dari keturunan, kemampuan dan wilayah (Daldjoeni, 1998).

Setiap permukiman memiliki sebuah pola yang dipengaruhi oleh keadaan iklim, keadaan tanah, tata air, topografi dan ketersediaan sumber daya alam pada suatu wilayah. Selain itu Rapoport (1969) juga menyatakan bahwa, budaya masyarakat setempat merupakan faktor utama dalam terbentuknya sebuah pola permukiman. Dengan kata lain pola permukiman pada sebuah kawasan dapat berkembang sesuai budaya masyarakatnya atau keadaan kondisi fisik lingkungannya.

\subsection{Kampung Tematik}

Kampung tematik pada awalnya merupakan sebuah program untuk membangun dan penataan sebuah permukiman dengan tujuan mengatasi permukiman kumuh di beberapa sudut kota. Tetapi dalam pengembangannya tidak hanya permukiman kumuh saja yang dikembangkan menjadi kampung tematik, tetapi kampung-kampung kota yang memiliki potensi dengan cirikhas tersendiri juga muncul sebagai kampung tematik untuk memperkenalkan potensi kawasannya.

Pembangunan kampung-kampung tematik pada umumnya diharapkan sebagai pemecah masalah terkait permukiman kumuh yang ada. Pembangunan kampung tematik ini juga cenderung berorientasi pada pembangunan sektor perekonomian dan pariwisata (Akbar \& Alfian, 2018). Pada kampung tematik, tidak hanya peran pemerintah yang berperan dalam pembangunan permukiman, tetapi masyarakat juga sangat berperan penting dalam kelancaran pembangunan kawasannya sendiri. Menurut Martuti et al (2017), pelibatan partisipasi masyarakat beserta lembaga-lembaga yang ada bertujuan untuk membangun trademark aatau karakteristik lingkungan

PAWON: Jurnal Arsitektur, Nomor 01 Volume VI, Januari - Juni Tahun 2022, ISSN 2597-7636 
melalui peningkatan dan pengembangan potensi-potensi lokal yang dimiliki di wilayah tersebut.

Kampung tematik di Kota Malang sekarang sudah banyak bermunculan, terdapat beberapa permukiman yang dulunya merupakan sebuah permukiman kumuh berubah menjadi kampung yang memiliki potensi sebagai objek pariwisata. Beberapa kampung tematik tersebut yaitu, Kampung Warna Warni Jodipan, Kampung Payung, Kampung Tridi, Kampung Budaya Polowijen, Kampung Topeng, Kampung 3G, Kampung Kramat dan banyak lagi yang lainnya yang mulai bermunculan dan berkembang di Kota Malang.

\section{METODE PENELITIAN}

Metode penelitian yang digunakan dalam penelitian ini, yaitu menggunakan metode penelitian deskriptif kualitatif. Metode penelitian dengan deskriptif kualitatif ini dipilih dikarenakan untuk mengamati fenomena yang terjadi di lapangan, sehingga didapatkan data terkait karakteristik permukiman pada kampung tematik yang menjadi objek penelitian di Kota Malang. Penelitian diawali dengan survey awal yang didukung dengan literatur dalam upaya untuk mendapatkan referensi yang kuat melakui data primer dan sekunder yang memungkinkan peneliti melihat seluruh fenomena yang ada di lapangan. Penelitian dilakukan dengan pengamatan yang mendalam, fakta-fakta yang terjadi di lapangan dapat diperoleh dan dimengerti dengan jelas sehingga mendapatkan hasil yang dapat digunakan sebagai dasar penentuan karakteristik permukiman.

Fokus perhatian suatu penelitian terletak pada penentuan variabel yang merupakan aspek penting pada objek/subjek penelitian. Dalam melihat karakteristik permukiman menggunakan teori Doxiadis (1968), dari aspek fisik, seperti alam (nature), manusia (man), lindungan (shell), jaringan (network) dan aspek non fisik, seperti sosial budaya masyarakat (society). Hasil dari analisis akan didapatkan karakteristik dari setiap objek permukiman kampung tematik yang dijadikan sample penelitian. 


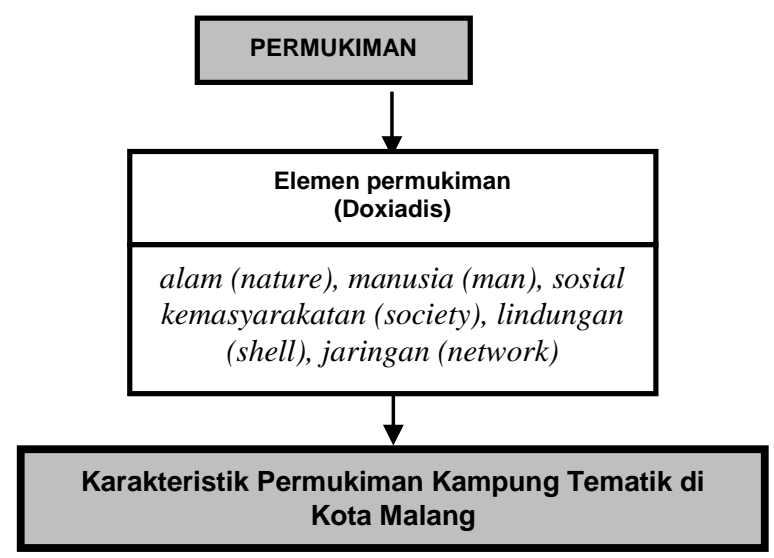

Gambar. 1

Diagram variabel penelitian.

Sumber: Rangkuman Penulis

\section{HASIL DAN PEMBAHASAN}

Penelitian ini mengambil dua kampung tematik yang ada di Kota Malang untuk dilihat karakteristik permukimannya. Pemilihan sampel kampung ini diambil dari pertimbangan pada perletakan posisi kampung, yaitu kampung tematik yang berada di tengah Kota Malang dan kampung tematik yang berada di pinggiran Kota Malang. Dari beberapa kampung tematik di Kota Malang, dipilih dua kampung, yaitu Kampung Tridi (Kelurahan Kesatrian, Kecamatan Blimbing, Kota Malang) dan Kampung Wisata Topeng (Dusun Baran, Kelurahan Tlogowaru, Kecamatan Kedungkandang, Kota Malang).

\subsection{Gambaran Umum Objek Penelitian}

a. Kampung Tridi

Kampung Tridi merupakan salah satu kampung wisata yang terletak di Jalan Temenggungan Ledok, RT $1-4$, RW 12, Kelurahan Kesatrian, Kecamatan Blimbing, Kota Malang. Lokasi Kampung Tridi ini tepat berseberangan dengan Kampung Warna-Warni Jodipan yang hanya dibatasi oleh Sungai Brantas. Kampung Tridi ini resmi dibuka pada bulan juli tahun 2016 dan menjadi salah satu pilihan destinasi wisata di Kota Malang dengan menonjolkan konsep Kampung Tematik. Potensi yang dimiliki Kampung Tridi ini adalah kawasan lingkungan permukiman yang unik dan menarik dengan warna warni rumah-rumah yang beragam di area permukiman, selain itu terdapat pula lukisan-lukisan dengan kesan tiga dimensi pada dinding-dinding bangunan. 

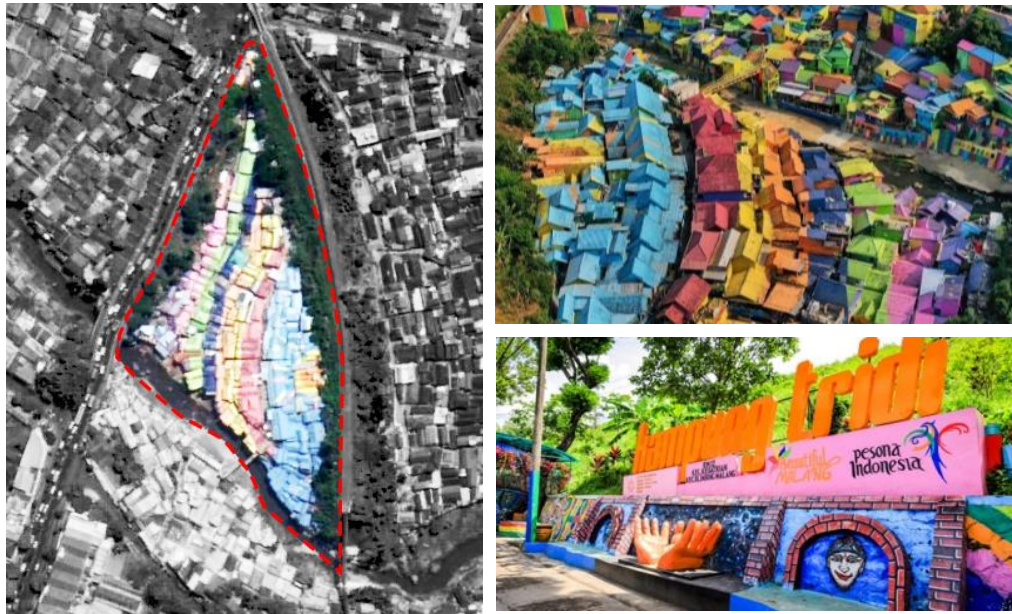

Gambar. 3

Citra kawasan Kampung Tridi.

Sumber: Olah Digital Citra Satelit

b. Kampung Topeng

Kampung Wisata Topeng merupakan kampung wisata yang menghadirkan suasana yang berbeda karena jauh dari tengah kota. Kampung wisata ini berada di wilayah dengan dataran yang cukup tinggi dan terdapat banyak pepohonan serta tanaman hias yang menjadikan suasana dia kampung wisata topeng ini terasa sejuk. Kampung Wisata Topeng ini berlokasi di Dusun Baran, Tlogowaru, Kecamatan Kedungkandang, Kota Malang. Kampung Topeng secara resmi dibuka pada tanggal 14 Februari 2017. Kampung Wisata Topeng menghadirkan sebuat tempat wisata edukatif yang memungkinkan pengunjung selain berfoto dan berekreasi, pengunjung dapat pula melakukan kegiatan membuat dan mewarnai topeng secara mandiri.

PAWON: Jurnal Arsitektur, Nomor 01 Volume VI, Januari - Juni Tahun 2022, ISSN 2597-7636 

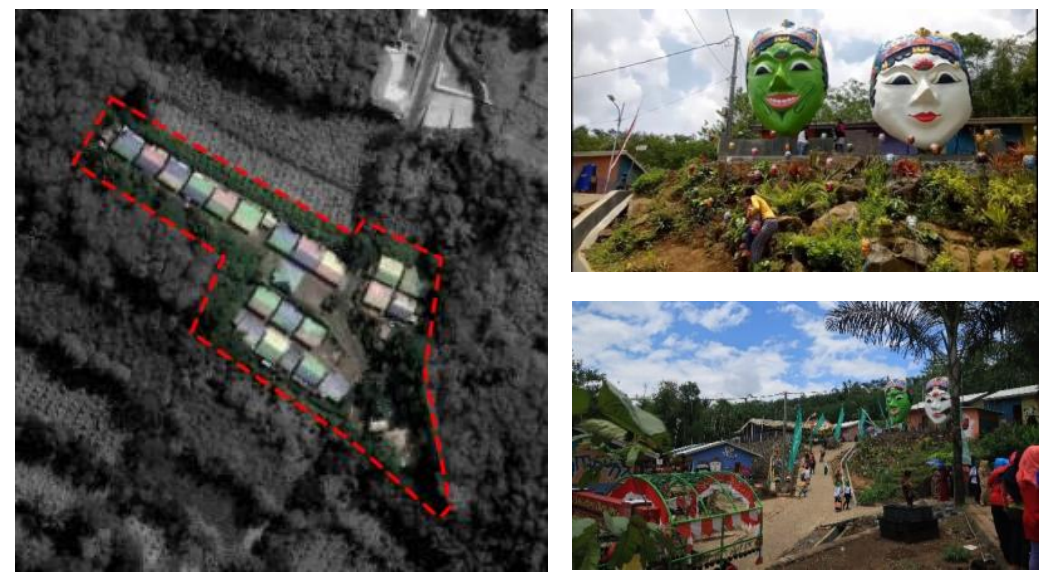

Gambar. 4

Citra kawasan Kampung Tridi.

Sumber: Olah Digital Citra Satelit

\subsection{Identifikasi dan Analisis Karakteristik Permukiman}

\subsubsection{Aspek Alam}

a. Kampung Tridi

Karakteristik lingkungan alam secara fisik permukiman Kampung Tridi ini berada di lingkungan sungai. Lingkungan binaan terfokus pada lingkungan rumah dan bangunan yang berada pada area bantaran sungai. Sungai menjadi salah satu faktor alam yang paling berpengaruh pada permukiman ini. Sungai yang mengalir melewati permukiman ini adalah Sungai Brantas, yang memberikan pengaruh pada penataan permukiman yang mengikuti bentuk sungai. Sungai Brantas ini merupakan sebuah pemisah antara destinasi Wisata Kampung Warna-Warni di Kelurahan Jodipan dan juga Kampung Tridi di Kelurahan Kesatrian Kota Malang.

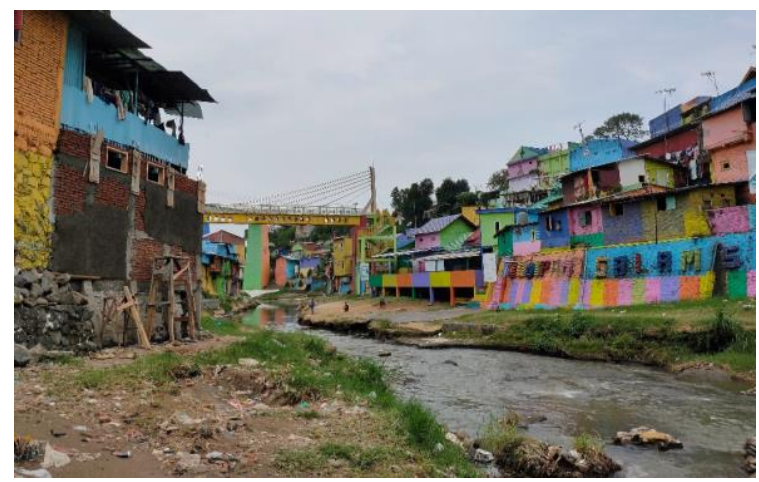

Gambar. 5

Sungai Brantas di Kampung Tridi.

Sumber: Survey

PAWON: Jurnal Arsitektur, Nomor 01 Volume VI, Januari - Juni Tahun 2022, ISSN 2597-7636 


\section{b. Kampung Topeng}

Karakteristik lingkungan alam pada permukiman Kampung Topeng ini masih didominasi oleh lingkungan hutan. Lokasi permukiman berada di area dataran tinggi yang masih dikelilingi oleh pepohonan dan kebun. Letak dari posisi kampung memang berada jauh dari pusat Kota Malang, ini didasari karena kampung ini merupakan permukiman baru. Sulitnya mencari lahan untuk permukiman baru di pusat kota, menjadikan kawasan pinggiran kota menjadi pilihan untuk membuka Kawasan permukiman yang baru. Dikarenakan letaknya yang berada di pinggiran kota, sehingga kawasan permukiman ini masih dipengaruhi oleh lingkungan alam berupa hutan.

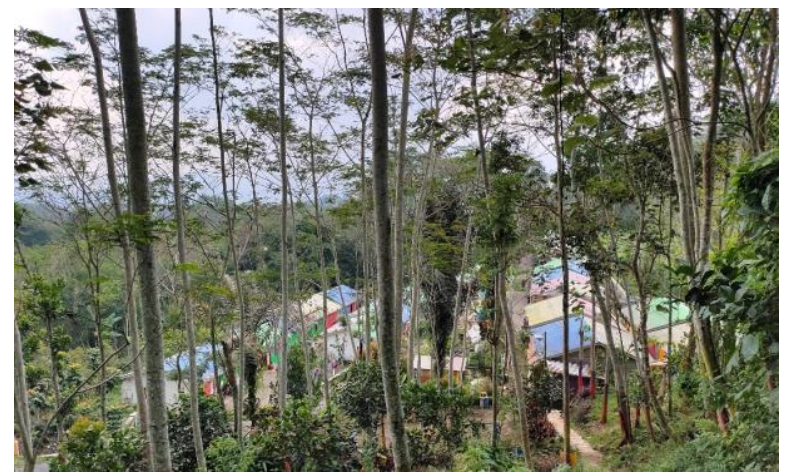

Gambar. 6

Kampung Topeng yang didominasi Hutan.

Sumber: Survey

\subsubsection{Aspek Manusia dan Sosial Kemasyarakatan}

a. Kampung Tridi

Perekonomian dari warga Kampung Tridi ini termasuk dalam kategori ekonomi kebawah. Hal ini dikarenakan banyaknya warga Kampung Tridi yang tidak memiliki pekerjaan tetap yang dapat menunjang keberlangsungan hidup meraka. Namun, semenjak dibukanya Kampung Tridi ini sebagai Tempat Wisata, perekonomian warga Kampung Tridi semakin terbantu. Sebagian besar warga Kampung Tridi yang awalnya tidak memiliki pekerjaan tetap, memanfaatkannya potensi dari kampung wisata ini sebagai peluang untuk bekerja dengan membuka tempat usaha, seperti warung, tempat cinderamata dan oleh-oleh.

Gotong-royong merupakan aspek dasar dalam kategori sosial kemasyarakatan warga Kampung Tridi ini. Hal ini terjadi karena hampir sebagian besar warga Kampung Tridi ikut andil dalam proses dan pengerjaan perawatan Kampung Tridi, sehingga gotong royong menjadi salah satu kegiatan sosial yang umum terjadi di Kampung Tridi ini. Dengan adanya kegiatan rutin ini, tentu saja berdampak pada aspek sosial

PAWON: Jurnal Arsitektur, Nomor 01 Volume VI, Januari - Juni Tahun 2022, ISSN 2597-7636 
kemasyarakatan warga Kampung tridi. Secara tidak langsung, akan selalu ada pertemuan antar warga setiap 1 bulan sekali guna meningkatkan kulitas dari objek Wisata Kampung Tridi.

b. Kampung Topeng

Masyarakat yang mendiami kampung topeng ini merupakan para gelandangan dan pengemis sekitar Kota Malang yang memang tidak mempunyai rumah untuk tinggal. Gelandangan dan Pengemis dipilih sebanyak 40 KK untuk ditempatkan di Kampung Topeng, dengan kriteria yaitu sudah berkeluarga, tidak memiliki peekerjaan serta warga asli Malang.

Kampung Topeng merupakan desa binaan pemerintah Kota Malang dengan program Desaku Menanti yang bertujuan untuk memberdayakan kembali masyarakat yang dulunya berprofesi sebagai gelandangan dan pengemis, agar memiliki sebuah pekerjaan baru dengan cara mengubah pola pikir masyarakat kampung topeng untuk terus produktif. Masyarakat Kampung Topeng diberikan pembinaan dan pelatihan mulai dari kalangan remaja untuk membuat organisasi kesenian dan belajar tari topeng. Dengan begitu, para remaja ini dapat memberikan penampilan tarian sehingga menjadi hiburan bagi pengunjung. Sedangkan untuk kalangan dewasa perempuan akan mendapat pembinaan dalam berkreasi topeng sehingga dapat memproduksi beberapa souvenir wisata topeng dan pelatihan mengenai kuliner yang dapat menghasilkan menu wisata kuliner pula.

\subsubsection{Aspek Lindungan}

a. Kampung Tridi

Pembahasan aspek lindungan pada permukiman ini dapat dikaitkan dengan hunian masyarakat Kampung Tridi. Jika dilihat secara umum, karakter fisik dari rumah masyarakat di permukiman ini lebih mengarah ke rumah kampung yang sederhana. Kesedarhanaan karakter rumah dipermukiman ini dikarenakan dasar terbentuk permukiman ini yang berawal dari kebutuhan akan tempat tinggal di keterbaasan lahan pada Kota Malang. Permukiman ini sebenarnya merupakan permukiman liar yang berkembang di daerah aliran Sungai Brantas dan tergolong kedalam permukiman kumuh.

Setelah dilakukan peremajaan pada permukiman ini, kulaitas rumah mulai membaik. Kondisi bangunan yang awalnya kurang terawat menjadi lebih indah dengan pemakaian cat warna-warni pada seluruh bangunan. Konsep kampung Tridi yang lebih menonjolkan pada mural, menjadikan dinding bangunan rumah masyarakat menjadi sebuah media pamer yang tepat. Dengan kepadatan bangunan yang tinggi, sehingga dapat menampilkan lukisan atau mural yang lebih banyak pada tiap dinding rumahnya.

PAWON: Jurnal Arsitektur, Nomor 01 Volume VI, Januari - Juni Tahun 2022, ISSN 2597-7636 

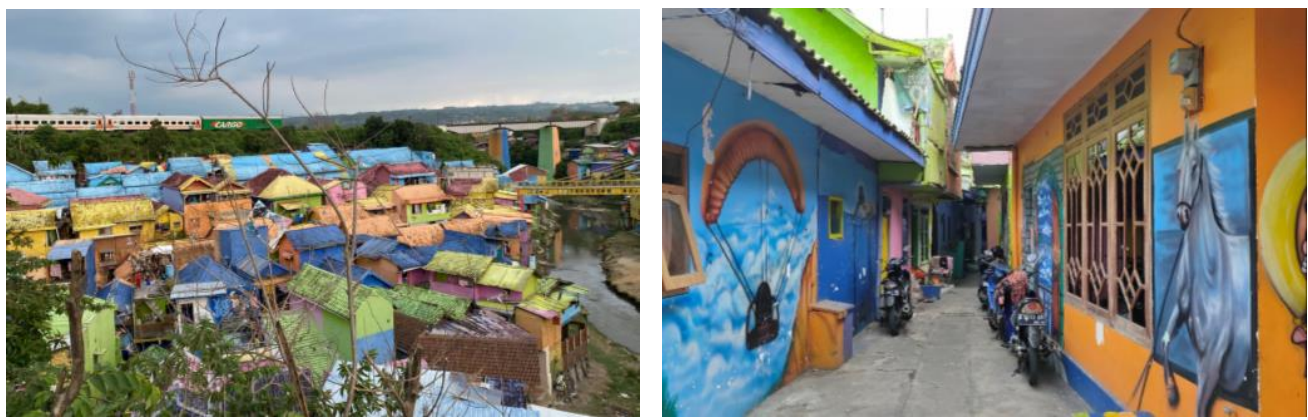

Gambar. 7

Bangunan hunian pada Kampung Tridi.

Sumber: Survey

\section{b. Kampung Topeng}

Aspek lindungan pada permukiman ini dapat dilihat dari bangunan hunian, hunian pada kampung ini masih tergolong kedalam tingkat kepadatan yang sangat rendah. Ini dikarenakan permukiman ini termasuk kedalam permukiman yang masih baru, permukiman ini hanya diisi oleh 40 kepala keluarga. Bangunan hunian pada kampung ini sangat sederhana sekali, mengingat permukiman ini memang dibangun pemerintah untuk memfasilitasi para gelandangan dan pengemis yang awalnya memang tidak memiliki tempat tinggal.

Dinding bangunan terbangun dengan material bata dengan bentuk bangunan memanjang kesamping dan satu bangunan difungsikan untuk 2 keluarga yang dibatasi dengan sekat dinding. Untuk atap pada bangunan hunian menggunakan atap pelana sederhana dengan material penutup atap memakai seng gelombang yang dicat warna warni. Karakteristik dari bangunan yang ada di kampung topeng sendiri dibuat penuh warna dan mencolok baik pada dinding bangunan ataupun atap bangunan. Hal ini sesuai dengan tujuan dari dibentuknya kampung topeng yaitu sebagai tempat wisata dan edukasi.
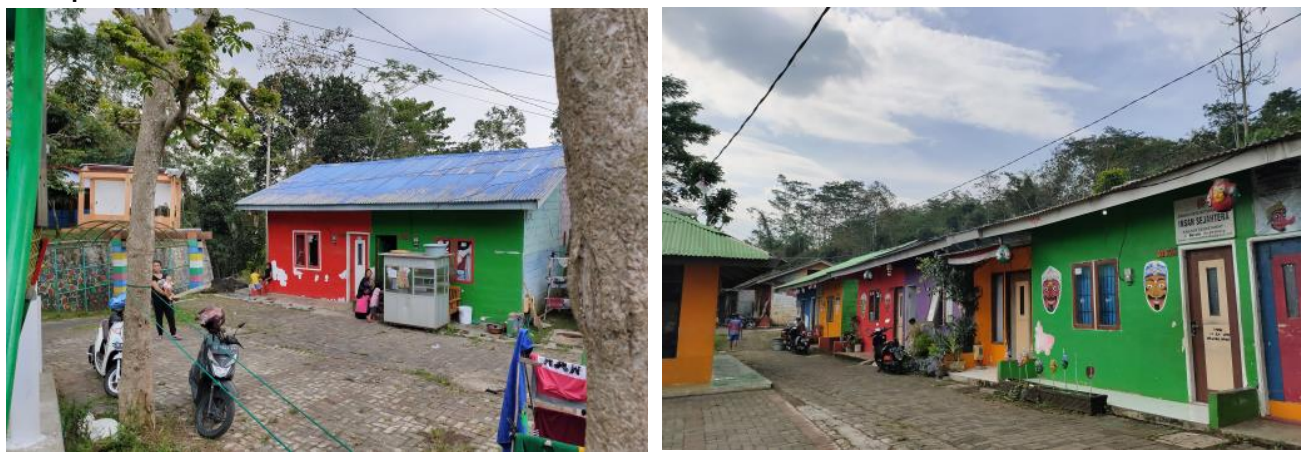

Gambar. 8

Bangunan hunian pada Kampung Topeng.

Sumber: Survey

PAWON: Jurnal Arsitektur, Nomor 01 Volume VI, Januari - Juni Tahun 2022, ISSN 2597-7636 


\subsubsection{Aspek Jaringan}

a. Kampung Tridi

Aspek jaringan pada permukiman ini mencakup jaringan jalan dan jaringan drainase. Terdapat 2 tipe jalan lingkungan yang ada di permukiman ini, yaitu jalan utama permukiman dan jalan gang yang menghubungkan jalan utama dengan area permukiman yang lebih mengarah kedalam. Lebar jalan pada permukiman ini cenderung berukuran kecil, dengan lebar jalan utama kurang lebih 3 meter dan jalan gang lebih kecil lagi dengan lebar kurang dari 2 meter. Material yang dipakai pada jalan lingkungan umumnya menggunakan material cor beton. Beberapa spot jalan dicat warna-warni untuk mempertegas kesan kawasan kampung wisata.

Selain jaringan jalan, terdapat pula jaringan drainase pada permukiman ini, fungsi jaringan drainase pada permukiman ini untuk saluran pembuangan air dari tiap rumah yang mengarah ke sungai sebagai tempat pembuangan akhir. Letak dari jaringan drainase ini berada di bawah jaringan jalan. Ini dikarenakan ukuran jalan yang cenderung kecil, sehingga tidak dimungkinkan untuk membuat drainase terbuka di kiri kanan jalan.

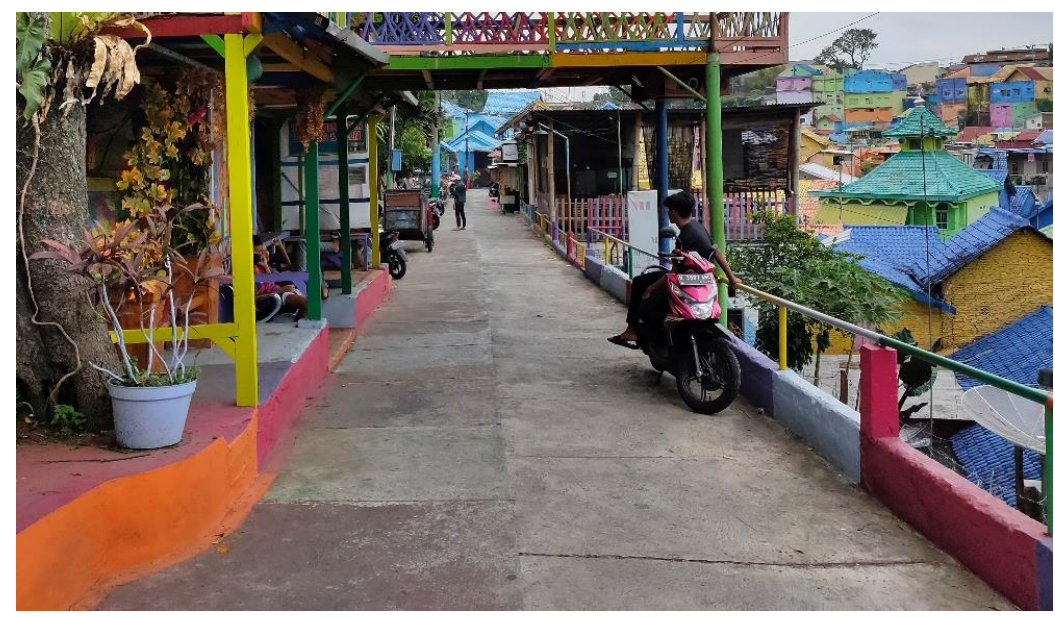

Gambar. 9

Jaringan jalan pada Kampung Tridi.

Sumber: Survey

\section{b. Kampung Topeng}

Dikarenakan Kampung Topeng merupakan kampung yang tergolong baru dan untuk peluasannya masih direncanakan, maka akses jaringan jalan dari Kampung Topeng ini masih sederhana. Jaringan pada permukiman ini hanya mencakup pada jaringan jalan. Jalan pada kampung wisata ini masih tergolong sangat sederhana, hanya terdapat jalur utama permukiman yang langsung terhubung ke rumah warga dan fasilitas penunjang lainnya. Jalan

PAWON: Jurnal Arsitektur, Nomor 01 Volume VI, Januari - Juni Tahun 2022, ISSN 2597-7636 
disini berfungsi sebagai akses sirkulasi dan juga sebagai area terbuka, dengan lebar jalan utama lebih dari 3,5 meter. Material yang dipakai pada jalan lingkungan ini adalah mengguakan paving block sebagai penutup jalannya.

Selain jaringan jalan, terdapat pula jaringan drainase pada permukiman ini. Letak dari jaringan drainase ini berada disisi kiri dan kanan jaringan jalan dengan menggunakan tipe drainase terbuka yang berukuran sekitar $20 \mathrm{~cm}$. Penggunaan dengan tipe ini dikarenakan lahan yang masih luas, sehingga untuk jaringan jalan dan drainase dapat dimaksimalkan dan disesuaikan dengan kebutuhan permukiman.

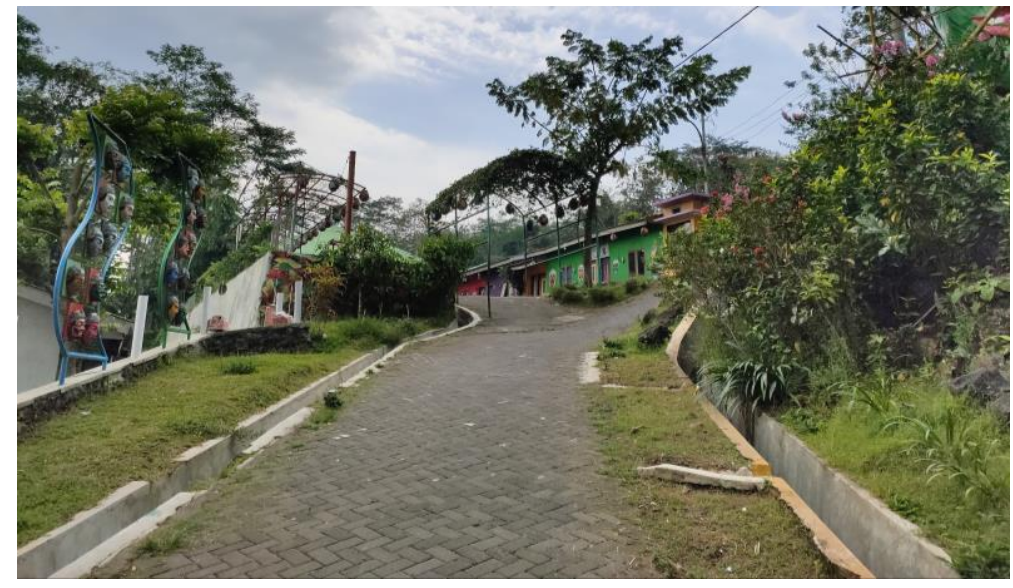

Gambar. 10

Jaringan jalan pada Kampung Topeng.

Sumber: Survey

\section{KESIMPULAN}

Hasil kesimpulan yang didapat dari dua permukiman, yaitu kampung tridi dan kampung topeng, masing-masing permukiman kampung tematik tersebut memiliki karakteristiknya masing-masing. Setelah dilakukan identifikasi, ditemukan beberapa karakteristik dengan keragaman dan keseragaman antara dua permukiman ini. Karakter spesifik dari kedua permukiman kampung tematik tersebut, diantaranya adalah:

a. Perbedaan yang paling jelas terlihat adalah pada karakteristik alam pada permukiman. Pada permukiman Kampung Tridi karakteristik lingkungan alam dipengaruhi oleh sungai, sungai yang melewati permukiman tersebut yaitu Sungai Brantas yang membelah Kota malang. Sedangkan pada Permukiman Kampung Topeng karakteristik alam yang mendominasi adalah hutan. Perbedaan karakteristik ini dipengaruhi oleh lokasi permukiman, yaitu pada Kampung Tridi berada di area pusat Kota Malang dan Kampung Topeng berada pada pingiran Kota Malang. 
b. Karakteristik dari kondisi sosial masyarakat pada dua perkampungan ini memiliki karakteristik yang kurang lebih sama, yaitu masyarakat dengan kondisi menengah ke bawah. Karakteristik ini sangat mempengaruhi berbagai aspek dari permukiman, seperti hunian dan Kawasan lingkungan permukiman.

c. Karakteristik lindungan juga terdapat perbedaan pada karakteristik huniannya, baik dari segi kepadatan hunian ataupun pada tampilan bangunan huniannya. Kepadatan hunian pada Kampung Tridi cenderung masuk dalam kepadatan yang sangat tinggi, sedangkan pada Kampung Topeng memiliki kepadatan yang sangat rendah. Hal ini diakibatkan oleh lokasi permukiman dan tujuan dari terbentuknya permukiman. Pada permukiman Kampung Tridi, terbentuknya permukiman diakibatkan karena adanya kebutuhan tempat tinggal pada area perkotaan, sedangkan pada Kampung Topeng terbentuknya permukiman tersebut dikarenakan penyediaan hunian oleh pemerintah untuk memfasilitasi para gelandangan dan pengemis yang tidak memiliki tempat tinggal. Untuk tampilan hunian pada dua kampung tersebut memiliki tampilan yang kurang lebih sama, dengan dominasi warna-warni pada bangunan.

d. Karakteristik dari aspek jaringan juga memiliki kemiripan. Hal ini didasari karena tujuan dari pengolahan permukiman yang dijadikan sebagai tempat wisata, sehingga perbaikan dan peremajaan kawasan dilakukan pada permukiman, salah satunya pada aspek jaringan. Aspek jaringan pada kedua permukiman ini didominasi oleh jalan yang sudah diperkeras dengan menggunakan material paving atau cor beton dan diberikan ornamentasi dengan pewarnaan pada jalan. Selain itu terdapat pula jaringan drainase pada permukiman yang dijadikan sebagai jalur air buangan dari hunian penduduk. 


\section{DAFTAR PUSTAKA}

Akbar, T. \& Alfian, F. (2018). Kampung Tematik Sebagai Bentuk Partisipasi Masyarakat Dalam Permasalahan Permukiman Kumuh di Kota Malang. WAHANA. 70 (2): 37-48

Daldjoeni, N. (1998). Geografi Kota dan Desa. Bandung: PT. Alumni.

Doxiadis, C.A. (1968). Ekistics: An Introduction to the Science of Human Settlements. London Hutchinson.

Martuti, N. K. T., Hidayah, I. \& Sumaryanti, T. (2017). Preferensi Masyarakat Terhadap Program Kampung Tematik di Kota Semarang. Riptek. 2 (2): $11-22$

Pemerintah Kota Malang (2015) Keputusan Walikota Malang Tentang Penetapan Lingkungan Perumahan dan Permukiman Kumuh 2015

Pemerintah Republik Indonesia. (2011) Undang-Undang Republik Indonesia Nomor 1 Tahun 2011 Tentang Perumahan Dan Kawasan Permukiman Rapoport, A. (1969). House Form and Culture. New Jersey: Printice Hall. 